\title{
Effects of dry period length and dietary energy source on milk yield, energy balance, and metabolic status of dairy cows over 2 consecutive years: Effects in the second year
}

\author{
J. Chen, ${ }^{*}$ G. J. Remmelink,† J. J. Gross,‡ R. M. Bruckmaier,ł B. Kemp, ${ }^{*}$ and A. T. M. van Knegsel ${ }^{* 1}$ \\ *Adaptation Physiology Group, Department of Animal Sciences, Wageningen University, and \\ tLivestock Research, Wageningen University and Research Centre, PO Box 338, 6700 AH Wageningen, the Netherlands \\ $¥$ Veterinary Physiology, Vetsuisse Faculty, University of Bern, Bremgartenstrasse 109a, CH-3012 Bern, Switzerland
}

\begin{abstract}
The objective of the current study was to evaluate the effect of dry period (DP) length on milk yield, energy balance (EB), and metabolic status in cows fed a lipogenic or glucogenic diet in the second year after implementation of DP and dietary treatments. HolsteinFriesian dairy cows $(\mathrm{n}=167)$ were assigned randomly to 1 of 3 DP lengths $(0,30$, or $60 \mathrm{~d})$ and 1 of 2 early lactation diets (glucogenic or lipogenic) for 2 consecutive years. Results of the first year were reported previously. In the second year, 19 cows in the 0-d DP group were attributed to a new group $(0 \rightarrow 67 \mathrm{~d}$ DP $)$ because these cows had a milk yield of $<4 \mathrm{~kg} / \mathrm{d}$ at least $30 \mathrm{~d}$ before expected calving date and were dried off. Milk yield was recorded and EB was calculated from wk -8 to 9 relative to calving. Blood samples were taken weekly from wk -3 to 8 relative to calving. Liver samples were taken in wk $-2,2$, and 4 relative to calving. At the onset of lactation, cows with a 0 -d or $0 \rightarrow 67$-d DP had greater body condition score (BCS) than cows with a $60-\mathrm{d}$ DP. During the first 9 wk, cows with a 0 - or $30-\mathrm{d}$ DP produced 5.0 and $4.3 \mathrm{~kg}$ less milk per day, respectively, but had similar EB compared with cows with a 60-d DP. Cows with a 0 - or 30-d DP produced additional milk precalving, which could compensate milk yield losses in the first $9 \mathrm{wk}$ postcalving. Cows with a 0-d DP did not have milk yield losses or improve EB in the second year as much as in the first year. Cows with a 0-d DP had greater plasma insulin and insulin-like growth factor-I (IGF-I) and lower liver triacylglycerol concentrations than cows with other DP lengths. Cows with a $0 \rightarrow 67$-d DP had lower EB, and greater plasma free fatty acids (FFA) and $\beta$-hydroxybutyrate (BHB) concentrations than cows with other DP lengths. Feeding a glucogenic diet increased plasma glucose, IGF-I, and insulin concentrations, and decreased plasma FFA,
\end{abstract}

Received December 10, 2015.

Accepted February 8, 2016.

${ }^{1}$ Corresponding author: Ariette.vanKnegsel@wur.nl
BHB, and urea concentrations compared with a lipogenic diet, independent of DP length. In conclusion, omitting the DP or feeding a glucogenic diet improved metabolic status in early lactation of the second year after implementation of DP length and dietary treatments, although effects of omitting the DP were less pronounced in the second year than in the first year. The less pronounced improvement of EB in the second year was related to the high BCS at the onset of lactation and reduced milk yield losses in cows with a $0-d$ DP.

Key words: continuous milking, energy metabolism, long-term effect

\section{INTRODUCTION}

The management strategy of drying off dairy cows at 6 to 8 wk before calving has been generally accepted since the beginning of last century, although the milk yield of modern dairy cows in late lactation has increased considerably (Bachman and Schairer, 2003). During the past few years, shortening or omitting the dry period (DP) in high-yielding dairy cows has received considerable attention. It was reported that shortening or omitting the DP improved energy balance (EB) in the subsequent lactation because of reduced milk yield in early lactation (van Knegsel et al., 2014). This improved EB is related to an improved metabolic status in early lactation, indicated by decreased plasma concentrations of free fatty acids (FFA; de Feu et al., 2009), BHB (Andersen et al., 2005), and liver triacylglycerol (TAG; Chen et al., 2015a), and increased plasma concentrations of insulin (Andersen et al., 2005), glucose (Rastani et al., 2005), and IGF-I (de Feu et al., 2009). In addition, days from calving to first ovulation and days from calving to pregnancy were reduced after shortening or omitting the DP (Rastani et al., 2005; Watters et al., 2009; Chen et al., 2015b).

Most studies investigated only consequences of shortening or omitting the DP for the lactation immediately following the DP length treatment (the first year). The 
effect of shortening or omitting the DP on milk yield, $\mathrm{EB}$, metabolic status, and fertility over consecutive years is still unclear. To our knowledge, only one controlled study has investigated the effect of omitting the DP on milk yield over 2 consecutive years (Rémond et al., 1997). Those authors found that omitting the DP over 2 consecutive years was difficult to implement on all cows because of the challenge in maintaining milk secretion in late lactation. In that study, however, milk yield was relatively low and the authors discussed that omitting the DP is a possible management strategy for cows with persistent and high milk yield. Therefore, it can be hypothesized that omitting the DP over 2 consecutive years is possible in cows with persistent and high milk yield, and it could improve EB and metabolic status in early lactation of the second year, as in the first year after implementation of DP length treatment.

In the first year after DP length treatment, feeding a glucogenic diet in early lactation improved EB further by a reduction in milk fat content (van Knegsel et al., 2014) and decreased plasma BHB concentration independent of DP length (Chen et al., 2015a). However, the effects of dietary energy source and its interaction with DP length on milk yield, EB, and metabolic status over 2 consecutive years have not been studied. We can hypothesize that feeding a glucogenic diet in early lactation of the second year also improves EB and metabolic status compared with a lipogenic diet as found in the first year.

In the current study, cows were followed for 2 consecutive years with the same DP management strategy and dietary strategy in each year. Results of the first year after implementation of DP and dietary treatments on EB and milk yield (van Knegsel et al., 2014), metabolites and metabolic hormones (Chen et al., 2015a), and fertility (Chen et al., 2015b) were reported previously. The objective of this study was to evaluate the influence of DP length on milk yield, EB, and metabolic status in cows fed a lipogenic or glucogenic diet during early lactation in the second year after start of DP length and dietary treatments.

\section{MATERIALS AND METHODS}

\section{Animals and Experimental Design}

The Institutional Animal Care and Use Committee of Wageningen University approved the experimental protocol. A total of 167 Holstein-Friesian dairy cows (60 primiparous and 107 multiparous) were selected from the Dairy Campus Research dairy herd (WUR Livestock Research, Lelystad, the Netherlands) for this experiment. The experimental design, DP lengths, and dietary contrasts have been reported previously (van Knegsel et al., 2014). Briefly, dairy cows were blocked by parity, expected calving date, milk yield in previous lactation, and BCS. Within blocks, cows were assigned at random to 1 of $3 \mathrm{DP}$ lengths $(0,30$, or $60 \mathrm{~d})$ and 1 of 2 early lactation diets (glucogenic or lipogenic). The drying-off protocol for cows with the 30- or 60-d DP consisted of a transition to the far-off ration at $d 7$ before drying-off, and milking once daily at d 4 before drying-off cows. Cows with a 30-d or 60-d DP were treated with an intramammary antibiotic at drying off (Supermastidol, Virbac Animal Health, Barneveld, the Netherlands). Before calving, lactating cows were fed a lactation diet supporting $25 \mathrm{~kg}$ of milk. All cows were fed $1 \mathrm{~kg} / \mathrm{d}$ of glucogenic or lipogenic concentrate from $10 \mathrm{~d}$ before the expected calving date. From calving until 100 DIM, the supply of concentrates increased stepwise by $0.5 \mathrm{~kg} / \mathrm{d}$ until it reached $8.5 \mathrm{~kg} / \mathrm{d}$. After 100 DIM, all cows were fed the standard lactation concentrate. The main ingredient for the glucogenic concentrate was corn and the main ingredients for the lipogenic concentrate were sugar beet pulp, palm kernel, and rumen-protected palm oil. Forage was offered ad libitum throughout the study and was composed of grass silage, corn silage, wheat straw, and rapeseed meal or soybean meal (51:34:2:13, DM basis). Diets were formulated to be isocaloric [net energy basis; Dutch net energy evaluation (VEM) system; Van Es, 1975] and equal in intestinal digestible protein and degraded protein balance (DVE/OEB) system (Tamminga et al., 1994). Cows were housed in a freestall with a slatted floor and cubicles, and were milked twice daily (0500 and $1630 \mathrm{~h}$ ).

We planned for cows to have the same DP length and diet over 2 consecutive years. Results of the first year after implementation of DP and dietary treatments on EB and milk yield (van Knegsel et al., 2014), metabolites and metabolic hormones (Chen et al., 2015a), and fertility (Chen et al., 2015b) were reported previously. After the first year, 18 cows were excluded due to nonpregnancy ( 8 cows with a 0 -d DP, 8 cows with a $30-d$ DP, 2 cows with a 60-d DP), 8 cows were excluded due to leg problems ( 3 cows with a 0 -d DP, 3 cows with a 30-d DP, 2 cows with a 60-d DP), and 3 cows with a $0-d$ DP were excluded due to udder problems, 8 cows were excluded due to other reasons such as abortion, and pneumonia ( 3 cows with a 0 -d DP, 3 cows with a $30-d$ DP, 2 cows with a 60-d DP). Therefore, the second year started with 130 cows (39 cows with a 0-d DP, 41 cows with a $30-d$ DP, and 50 cows with a $60-d$ DP). However, 19 cows in the 0-d DP group were attributed to a new group $(\mathbf{0} \rightarrow \mathbf{6 7 - d} \mathbf{D P})$ because these cows had a milk yield of $<4 \mathrm{~kg} / \mathrm{d}$ at least $30 \mathrm{~d}$ before expected calving 
date and were dried off without use of intramammary antibiotics.

\section{BCS, Milk Yield, and EB}

Body condition was scored (1-5 scale) monthly. Body weight was recorded after each milking and averaged per week from wk -8 to 9 relative to calving. Milk yield and feed intake were recorded daily (Insentec BV, Marknesse, the Netherlands) per cow and averaged per week from wk -8 to 9 relative to calving. Energy balance was calculated per week according to the VEM system (Van Es, 1975; CVB, 2005) as the difference between VEM supplied with feed and VEM required for maintenance and milk yield. The VEM required for animal maintenance is $42.4 \mathrm{VEM} / \mathrm{kg}^{0.75}$ per day $(1,000 \mathrm{VEM}=$ 6.9 MJ of net energy) and the VEM required for milk yield is $443 \mathrm{VEM} / \mathrm{kg}$ of fat- and protein-corrected milk (FPCM; Van Es, 1975). A correction factor to scale requirements to an average cow was applied in calculating the maintenance and milk energy requirements, as described by Van Es (1975).

\section{Blood and Liver Tissue Sampling and Analysis}

Blood and liver tissue sampling and analysis have been reported previously (Chen et al., 2015a). Briefly, blood samples were taken weekly from wk -3 to 8 relative to calving and liver biopsies were taken in wk -2 , 2 , and 4 relative to calving. Blood samples were kept on ice for a maximum of $2 \mathrm{~h}$ until they were centrifuged at $2,900 \times g$ for $10 \mathrm{~min}$ at $4^{\circ} \mathrm{C}$ and subsequently stored at $-20^{\circ} \mathrm{C}$ until analysis. Plasma and liver samples were analyzed for indicators of metabolic status. Concentrations of glucose and urea were measured using commercial kits no. 61269 and no. 61974 from bioMérieux (Marcy l'Etoile, France), as previously described (Graber et al., 2012). Concentrations of FFA and BHB were measured enzymatically using kit no. 994-75409 from Wako Chemicals (Neuss, Germany) and kit no. RB1007 from Randox Laboratories (Ibach, Switzerland), respectively, as previously described (Graber et al., 2012). Insulin-like growth factor-I and insulin were measured using radioimmunoassay, as previously described (Vicari et al., 2008). Liver tissue samples were kept on ice in a $0.9 \% \mathrm{NaCl}$ solution for up to $2 \mathrm{~h}$ and subsequently stored at $-20^{\circ} \mathrm{C}$ until analysis. Liver tissue sample with a wet weight of approximately $150 \mathrm{mg}$ was homogenized for $15 \mathrm{~s}$ and TAG was extracted from liver sample using $0.5 \mathrm{~mol} / \mathrm{L} \mathrm{KOH}$ in ethanol for $30 \mathrm{~min}$ at $70^{\circ} \mathrm{C}$, and then $2.5 \mathrm{~mol} / \mathrm{L}$ perchloric acid was added to neutralize the mixture. The concentration of liver TAG was determined though enzymatic colorimetric analysis using the Triacylglycerols LiquiColor Mono kit (Human Gesellschaft fur Biochemica undDiagnostica mbH, Wiesbaden, Germany) according to the manufacturer's instructions.

\section{Statistical Analysis}

Results of the first year after implementation of DP and dietary treatments on EB, milk yield, BCS, BW (van Knegsel et al., 2014), metabolites and metabolic hormones (Chen et al., 2015a), and fertility (Chen et al., 2015b) were reported previously. For the second year after implementation of DP and dietary treatments, repeated-measurement analyses consisting of weeks relative to calving with cows as the subject were performed using PROC MIXED in SAS 9.2 (version 9.2; SAS Institute Inc., Cary, NC). A first-order autoregressive structure $[\mathrm{AR}(1)]$ was the best fit and was used to account for within-cow variation. Statistical analyses were performed separately for pre- and postcalving data.

Milk yield, DMI, EB, BW, BCS, plasma metabolites and hormones, and liver TAG were analyzed with DP length $(0,30,60$, or $0 \rightarrow 67 \mathrm{~d}$ ), diet (glucogenic or lipogenic), parity $(3,4$, or $>4)$, time, and their 2-way interactions included as fixed effects (model 1). For precalving analyses, preliminary analyses showed that the interactions of diet with DP length, time, and parity were not significant $(P>0.05)$. For postcalving analyses, preliminary analyses showed that interactions of DP length with diet and parity and of diet with parity were not significant $(P>0.05)$. These variables were therefore excluded from their respective models.

To investigate the differences in milk yield and EB between the first and second year in older cows (parity $>2$ ) with different DP lengths, year (1 or 2), DP length $(0,30$, or $60 \mathrm{~d})$, diet (glucogenic or lipogenic), time, and the interactions between year and DP length were assessed as fixed effects (model 2).

Preliminary analysis showed that precalving BCS was related to milk composition, EB, and plasma metabolites and varied among DP length treatments. To analyze whether the precalving BCS had an explanatory effect on postcalving milk yield, EB, and metabolic status, cows were classified into 2 groups based on average BCS $(<3.75$ or $\geq 3.75)$ during mo -2 and -1 relative to calving. Milk yield, milk composition, DMI, $\mathrm{EB}, \mathrm{BW}$, plasma metabolites and hormones, and liver TAG postcalving were analyzed with BCS $(<3.75$ or $\geq 3.75)$, DP length $(0,30,60$, or $0 \rightarrow 67 \mathrm{~d}$ ), diet (glucogenic or lipogenic), parity $(3,4$, or $>4)$, time, and the interactions between BCS classification and other fixed effects included as fixed effects (model 3). Preliminary 
analysis showed that the interaction of BCS with diet was not significant $(P>0.05)$, and was therefore excluded from the model.

For comparison of DP lengths, $P$-values are presented after a Bonferroni adjustment. Values are presented as least squares means and standard error of the means, unless otherwise stated. Differences are considered significant if $P<0.05$, and trends are discussed if $P \leq$ 0.10 .

\section{RESULTS}

\section{Dry Period Length Before the Second Calving}

Actual days dry before the second calving were $0 \pm$ $0 \mathrm{~d}, 40 \pm 5 \mathrm{~d}, 64 \pm 2 \mathrm{~d}$, and $67 \pm 8 \mathrm{~d}$ (means $\pm \mathrm{SEM}$ ) for cows with a $0-, 30-, 60-$, or $0 \rightarrow 67-d \mathrm{DP}$, respectively.

\section{Precalving Milk Yield, EB, BCS, Plasma Metabolites, Hormones, and Liver TAG}

During the last 8 wk before the second calving, cows with a 0 -d or $0 \rightarrow 67$-d DP had greater BCS compared with cows with a $60-\mathrm{d}$ DP (Table 1 ). Cows with a 0 - or 30 -d DP produced $7.2 \pm 0.8$ or $4.1 \pm 0.5 \mathrm{~kg}$ of milk per day, respectively (Figure 1), and $8.6 \pm 0.9$ or $5.3 \pm 0.6$ of FPCM per day, respectively. Cows with a $60-\mathrm{d}$ DP had greater EB compared with cows with other DP lengths (Figure 1). Cows with a $0 \rightarrow 67$-d DP had lower DMI compared with cows with other DP lengths.

Cows with a 0-d DP had greater plasma concentrations of BHB and urea compared with cows with other DP lengths. Cows with a 0-d DP had greater plasma insulin concentration compared with cows with a $60-\mathrm{d}$ DP. In addition, cows with a $0 \rightarrow 67$-d DP had greater plasma FFA concentration compared with cows with a 60-d DP.

\section{Postcalving Milk Yield, EB, and BCS}

During 9 wk after the second calving, cows with a 0 - or 30-d DP produced 5.0 or $4.3 \mathrm{~kg}$ less milk per day, respectively, compared with cows with a $60-d$ DP (Table 2; Figure 1). Cows with a 0-d DP had higher natural logarithm of SCC ( $\mathrm{LnSCC}$ ) and greater BCS compared with cows with a 60-d DP. Cows with a 60-d DP produced greater FPCM compared with cows with a 30 -d DP. In addition, cows with a $0 \rightarrow 67$-d DP had greater BW and lower DMI compared with cows with a 60-d DP, but had lower EB compared with cows with a 0 - or 30 -d DP. Cows with a $0 \rightarrow 67$-d DP had lower energy intake (EI) and greater BCS compared with cows with a $30-$ or $60-d$ DP. Cows fed a glucogenic diet had lower milk fat percentage and tended to have greater milk yield $(P=0.06)$ compared with cows fed a lipogenic diet. Diet did not affect DMI, EB, BW, or BCS in early lactation.

\section{Postcalving Plasma Metabolites, Hormones, and Liver TAG}

During 9 wk after the second calving, cows with a 0 -d DP had greater plasma insulin and IGF-I concentrations but lower liver TAG concentration compared with cows with other DP lengths (Table 3). Cows with a $0 \rightarrow 67$-d DP had greater plasma concentrations of FFA and BHB and a lower plasma urea concentration compared with cows with other DP lengths. In addition, an interaction of DP length $\times$ time was present for plasma FFA concentration, showing that plasma FFA concentration increased from wk 3 to 4 in cows with a $0 \rightarrow 67-d$ DP, but not in cows with other DP lengths (Figure 2). Interaction of diet $\times$ time showed that liver TAG concentration decreased from wk 2 to 4 in cows fed a glucogenic diet but not in cows fed a lipogenic diet (Figure 3). Cows fed a glucogenic diet had greater plasma concentrations of glucose, IGF-I, and insulin, but lower plasma concentrations of FFA, BHB, and urea compared with cows fed a lipogenic diet. Postcalving, time effects were significant for plasma FFA, BHB, glucose, urea, IGF-I, insulin, and liver TAG concentrations.

\section{Relationships Between BCS and Milk Yield, EB, and Metabolic Status}

In early lactation, cows with precalving BCS $\geq 3.75$ had greater FPCM, milk fat percentage, BW, and plasma concentrations of $\mathrm{FFA}$ and $\mathrm{BHB}$, but lower EB compared with cows with precalving BCS $<3.75$, independent of DP length (Table 4). Interaction of DP length $\times$ BCS classification was present for EI. Cows with a $0 \rightarrow 67$-d DP had lower EI $\left(984 \pm 47 \mathrm{~kJ} / \mathrm{kg}^{0.75}\right.$ per day) compared with cows with a $60-d$ DP $(1,108 \pm$ $13 \mathrm{~kJ} / \mathrm{kg}^{0.75}$ per day) when cows had precalving BCS $<3.75$, whereas cows with a $30-d$ DP $(956 \pm 21 \mathrm{~kJ} /$ $\mathrm{kg}^{0.75}$ per day) had lower EI compared with cows with a 60-d DP $\left(1,032 \pm 24 \mathrm{~kJ} / \mathrm{kg}^{0.75}\right.$ per day) when cows had precalving BCS $\geq 3.75$. Furthermore, cows with precalving $\mathrm{BCS} \geq 3.75$ tended to have lower DMI $(P=$ $0.07)$ and forage intake $(P=0.07)$ compared with cows with precalving $\mathrm{BCS}<3.75$.

When adding precalving BCS classification as a fixed effect in the model, DP length effects were no longer present for milk fat percentage $(P=0.78)$, BW $(P=$ $0.47)$, or plasma concentrations of FFA $(P=0.08)$, BHB $(P=0.42)$, and urea $(P=0.11)$. Dry period length effects changed for EB and concentrate intake 
Table 1. Least squares means for DMI, energy balance (EB), metabolites and hormones of dairy cows precalving during a dry period of 0,30 , 60 , or $0 \rightarrow 67 \mathrm{~d}^{1}$ and fed either a glucogenic $(\mathrm{G})$ or a lipogenic $(\mathrm{L})$ diet

\begin{tabular}{|c|c|c|c|c|c|c|c|c|c|c|c|c|c|c|}
\hline \multirow[b]{2}{*}{ Item } & \multicolumn{4}{|c|}{ Dry period length $(\mathrm{d})$} & \multirow[b]{2}{*}{$\mathrm{SEM}^{2}$} & \multicolumn{2}{|c|}{ Diet } & \multirow[b]{2}{*}{ SEM } & \multicolumn{6}{|c|}{$P$-value ${ }^{3}$} \\
\hline & 0 & 30 & 60 & $0 \rightarrow 67$ & & $\mathrm{G}$ & $\mathrm{L}$ & & DPL & Diet & Time $^{4}$ & Parity & $\mathrm{DPL} \times \mathrm{P}$ & $\mathrm{DPL} \times \mathrm{T}$ \\
\hline Cows (no.) & 20 & 41 & 50 & 19 & & 66 & 64 & & & & & & & \\
\hline DMI $(\mathrm{kg} / \mathrm{d})$ & $16.3^{\mathrm{a}}$ & $15.0^{\mathrm{a}}$ & $15.2^{\mathrm{a}}$ & $12.9^{\mathrm{b}}$ & 0.4 & 14.7 & 15.1 & 0.3 & $<0.01$ & 0.24 & $<0.01$ & 0.16 & 0.87 & $<0.01$ \\
\hline $\mathrm{EB}^{5}\left(\mathrm{~kJ} / \mathrm{kg}^{0.75}\right.$ per day $)$ & $118^{\mathrm{b}}$ & $94^{\mathrm{b}}$ & $175^{\mathrm{a}}$ & $68^{\mathrm{b}}$ & 15 & 103 & 120 & 10 & $<0.01$ & 0.63 & $<0.01$ & 0.75 & 0.87 & $<0.01$ \\
\hline BW $(\mathrm{kg})$ & $808.6^{\mathrm{ab}}$ & $776.8^{\mathrm{b}}$ & $764.6^{\mathrm{b}}$ & $828.6^{\mathrm{a}}$ & 12.8 & 794.8 & 794.5 & 8.6 & $<0.01$ & 0.98 & $<0.01$ & 0.87 & 0.63 & $<0.01$ \\
\hline $\mathrm{BCS}^{6}$ & $3.8^{\mathrm{ab}}$ & $3.5^{\mathrm{b}}$ & $3.2^{\mathrm{c}}$ & $4.2^{\mathrm{a}}$ & 0.1 & 3.7 & 3.7 & 0.1 & $<0.01$ & 0.83 & 0.43 & $<0.01$ & 0.83 & 0.18 \\
\hline Cows (no.) & 16 & 33 & 44 & 19 & & 58 & 54 & & & & & & & \\
\hline Free fatty acids $(\mathrm{mmol} / \mathrm{L})$ & $0.15^{\mathrm{ab}}$ & $0.17^{\mathrm{ab}}$ & $0.15^{\mathrm{b}}$ & $0.24^{\mathrm{a}}$ & 0.02 & 0.17 & 0.18 & 0.01 & 0.02 & 0.63 & $<0.01$ & 0.04 & 0.19 & 0.87 \\
\hline $\mathrm{BHB}^{7}(\mathrm{mmol} / \mathrm{L})$ & $0.55^{\mathrm{a}}$ & $0.41^{\mathrm{b}}$ & $0.42^{\mathrm{b}}$ & $0.40^{\mathrm{b}}$ & 0.04 & 0.45 & 0.44 & 0.03 & $<0.01$ & 0.58 & 0.01 & 0.53 & 0.43 & 0.78 \\
\hline Glucose $(\mathrm{mmol} / \mathrm{L})$ & 3.75 & 3.80 & 3.73 & 3.66 & 0.05 & 3.76 & 3.71 & 0.03 & 0.22 & 0.30 & $<0.01$ & $<0.01$ & 0.54 & 0.22 \\
\hline Urea $(\mathrm{mmol} / \mathrm{L})$ & $3.56^{\mathrm{a}}$ & $2.77^{\mathrm{b}}$ & $2.56^{\mathrm{b}}$ & $2.31^{\mathrm{b}}$ & 0.12 & 2.75 & 2.85 & 0.09 & $<0.01$ & 0.40 & 0.04 & 0.74 & 0.04 & 0.58 \\
\hline IGF-I (ng/mL) & 162.39 & 151.46 & 147.71 & 164.27 & 7.13 & 155.57 & 157.74 & 4.84 & 0.25 & 0.74 & $<0.01$ & $<0.01$ & 0.91 & 0.65 \\
\hline Insulin $(\mu \mathrm{IU} / \mathrm{mL})$ & $27.97^{\mathrm{a}}$ & $21.17^{\mathrm{ab}}$ & $20.65^{\mathrm{b}}$ & $22.51^{\mathrm{ab}}$ & 1.68 & 23.39 & 22.69 & 1.14 & 0.02 & 0.58 & $<0.01$ & 0.11 & 0.22 & 0.55 \\
\hline Cows (no.) & 10 & 23 & 22 & 13 & & 34 & 34 & & & & & & & \\
\hline $\begin{array}{l}\text { Liver triacylglycerol } \\
\text { (mg/g of wet weight) }\end{array}$ & 15.36 & 16.67 & 15.53 & 21.55 & 2.08 & 16.70 & 17.85 & 1.47 & 0.16 & 0.58 & $\mathrm{NM}^{8}$ & 0.70 & 0.26 & $\mathrm{NM}$ \\
\hline
\end{tabular}

${ }_{\mathrm{a}, \mathrm{b}}$ Values within the same row with different superscripts differ $(P<0.05)$.

${ }^{1}$ The study began with 130 cows (39 cows with a 0-d dry period, 41 cows with a 30-d dry period, and 50 cows with a 60-d dry period). However, 19 cows in the 0-d dry period group were attributed to a new group $(0 \rightarrow 67 \mathrm{~d}$ dry period) because these cows had a milk yield of $<4 \mathrm{~kg} / \mathrm{d}$ at least $30 \mathrm{~d}$ before expected calving date and were dried off without use of intramammary antibiotics.

${ }^{2} \mathrm{SEM}=$ pooled standard error of the least squares means.

${ }^{3} \mathrm{DPL}=$ dry period length; $\mathrm{T}=$ time; $\mathrm{P}=$ parity.

${ }^{4} \mathrm{Wk}-8,-7,-6,-5,-4,-3,-2$, and -1 relative to calving for DMI, EB, and BW; mo -2 and -1 relative to calving for BCS; wk $-3,-2$, and -1 relative to calving for plasma concentrations of free fatty acids, BHB, glucose, urea, IGF-I, and insulin; wk -2 relative to calving for liver triacylglycerol concentration.

${ }^{5}$ Energy balance; calculated with the VEM system (Van Es, 1975).

${ }^{6} \mathrm{On}$ a scale of 1 to 5 .

${ }^{7}$ Analyses were based on natural log-transformed data; back-transformed data are presented.

${ }^{8} \mathrm{NM}=$ not included in the model. 
after correcting for precalving BCS. After correcting for precalving BCS, cows with a 0-d DP had greater EB in early lactation compared with cows with a $60-d$ DP. Cows with a 30-d DP had lower concentrate intake compared with cows with a 60-d DP. Moreover, the effects of DP length were unchanged after correction for precalving BCS for milk yield, FPCM, milk lactose and protein percentage, LnSCC, DMI, forage intake, EI, EB, plasma concentrations of glucose, IGF-I, and insulin, and liver TAG concentration.

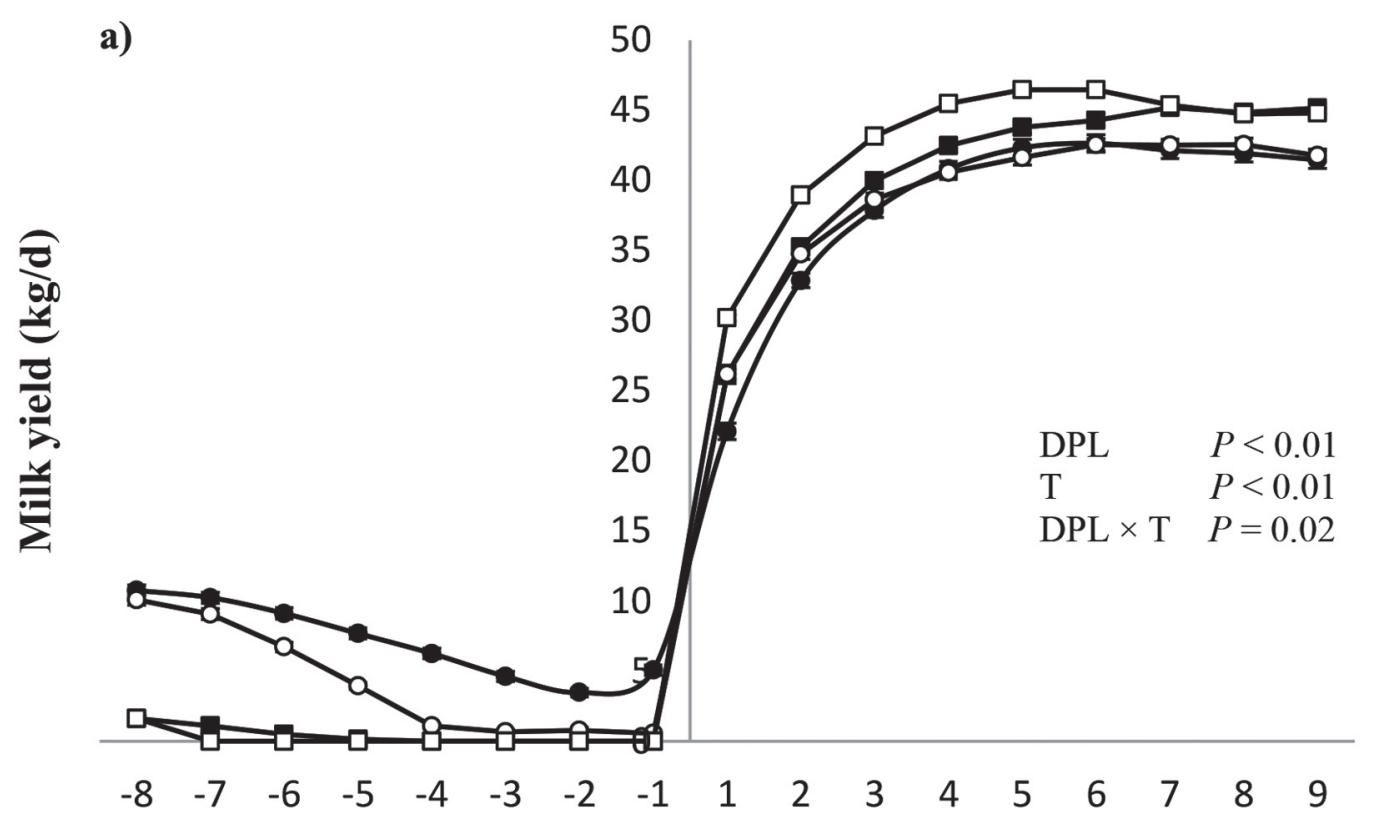

b)

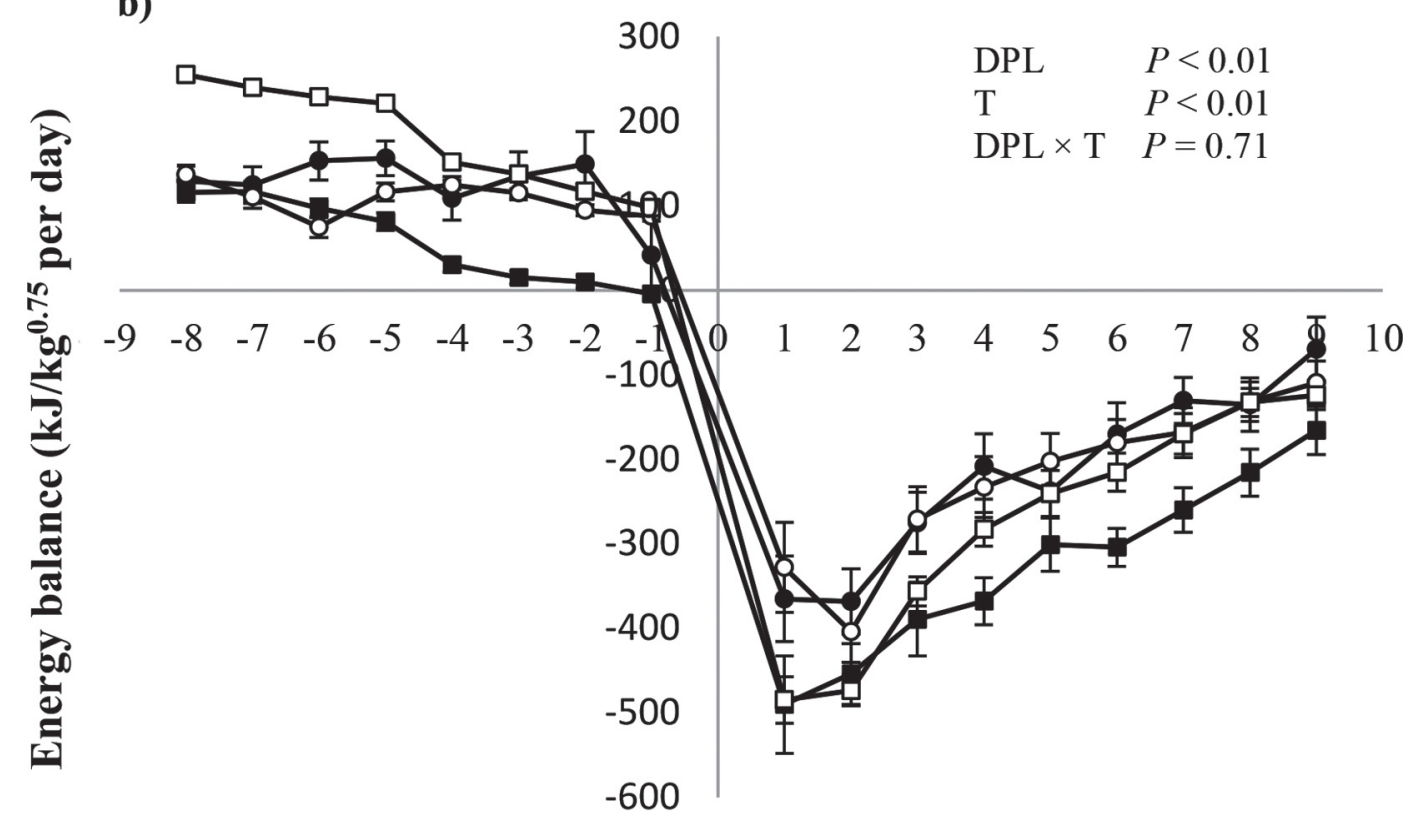

Week relative to calving

Figure 1. Milk yield $(\mathrm{kg} / \mathrm{d})$ and energy balance $\left(\mathrm{kJ} / \mathrm{kg}^{0.75}\right.$ per day) for cows with a 0 -d $(\bullet), 0 \rightarrow 67-\mathrm{d}(\boldsymbol{\square}), 30-\mathrm{d}(\bigcirc)$, or $60-\mathrm{d}(\square)$ dry period from wk -8 to 9 relative to calving. The study began with 130 cows $(39$ cows with a 0 -d dry period, 41 cows with a 30-d dry period, and 50 cows with a 60-d dry period). However, 19 cows in the 0 -d dry period group were attributed to a new group (0 $\rightarrow 67 \mathrm{~d}$ dry period) because these cows had a milk yield of $<4 \mathrm{~kg} / \mathrm{d}$ at least $30 \mathrm{~d}$ before expected calving date and were dried off without use of intramammary antibiotics. Values represent means and error bars represent the error of the means per dry period length per week. The statistical effects of dry period length (DPL), time $(\mathrm{T})$, and dry period length $\times$ time $(\mathrm{DPL} \times \mathrm{T})$ postcalving are indicated. 
Table 2. Least squares means for milk yield, milk composition, DMI, energy balance, and BCS of dairy cows in early lactation after a dry period of $0,30,60$, or $0 \rightarrow 67 \mathrm{~d}^{1}$ and fed either a glucogenic $(\mathrm{G})$ or a lipogenic $(\mathrm{L})$ diet

\begin{tabular}{|c|c|c|c|c|c|c|c|c|c|c|c|c|c|c|}
\hline \multirow[b]{2}{*}{ Item } & \multicolumn{4}{|c|}{ Dry period length (d) } & \multirow[b]{2}{*}{$\mathrm{SEM}^{2}$} & \multicolumn{2}{|c|}{ Ration } & \multirow[b]{2}{*}{ SEM } & \multicolumn{6}{|c|}{$P$-value ${ }^{3}$} \\
\hline & 0 & 30 & 60 & $0 \rightarrow 67$ & & G & $\mathrm{L}$ & & DPL & Diet & Time $^{4}$ & Parity & $\mathrm{DPL} \times \mathrm{T}$ & $\mathrm{D} \times \mathrm{T}$ \\
\hline Cows (no.) & 20 & 41 & 50 & 19 & & 66 & 64 & & & & & & & \\
\hline Milk yield $(\mathrm{kg} / \mathrm{d})$ & $37.8^{\mathrm{b}}$ & $38.5^{\mathrm{b}}$ & $42.8^{\mathrm{a}}$ & $40.6^{\mathrm{ab}}$ & 1.0 & 40.8 & 39.1 & 0.7 & $<0.01$ & 0.06 & $<0.01$ & 0.04 & 0.23 & 0.02 \\
\hline $\mathrm{FPCM}^{5}(\mathrm{~kg} / \mathrm{d})$ & $41.0^{\mathrm{ab}}$ & $40.9^{\mathrm{b}}$ & $44.4^{\mathrm{a}}$ & $43.6^{\mathrm{ab}}$ & 1.0 & 42.8 & 42.1 & 0.7 & $<0.01$ & 0.43 & $<0.01$ & 0.16 & 0.65 & 0.07 \\
\hline Lactose $(\%)$ & 4.50 & 4.51 & 4.51 & 4.49 & 0.03 & 4.51 & 4.49 & 0.02 & 0.94 & 0.21 & $<0.01$ & $<0.01$ & 0.87 & 0.35 \\
\hline Fat $(\%)$ & $4.61^{\mathrm{ab}}$ & $4.54^{\mathrm{ab}}$ & $4.41^{\mathrm{b}}$ & $4.80^{\mathrm{a}}$ & 0.08 & 4.48 & 4.70 & 0.06 & 0.02 & $<0.01$ & $<0.01$ & 0.25 & 0.98 & 0.08 \\
\hline Protein (\%) & $3.58^{\mathrm{a}}$ & $3.53^{\mathrm{a}}$ & $3.39^{\mathrm{ab}}$ & $3.30^{\mathrm{b}}$ & 0.06 & 3.47 & 3.43 & 0.04 & $<0.01$ & 0.38 & $<0.01$ & 0.44 & 0.86 & 0.96 \\
\hline $\operatorname{LnSCC}^{6}\left(\times 10^{3}\right.$ cells $\left./ \mathrm{mL}\right)$ & $5.1^{\mathrm{a}}$ & $4.8^{\mathrm{ab}}$ & $4.6^{\mathrm{b}}$ & $5.0^{\mathrm{ab}}$ & 0.12 & 4.9 & 4.9 & 0.09 & 0.02 & 0.84 & $<0.01$ & $<0.01$ & 0.47 & 0.60 \\
\hline DMI $(\mathrm{kg} / \mathrm{d})$ & $21.3^{\mathrm{ab}}$ & $20.8^{\mathrm{ab}}$ & $21.9^{\mathrm{a}}$ & $19.7^{\mathrm{b}}$ & 0.4 & 21.1 & 20.8 & 0.3 & $<0.01$ & 0.35 & $<0.01$ & 0.27 & 0.02 & 0.22 \\
\hline Concentrate $(\mathrm{kg} / \mathrm{d})$ & 6.9 & 6.9 & 6.9 & 6.9 & 0.0 & 6.9 & 6.9 & 0.0 & 0.20 & 0.13 & $<0.01$ & 0.20 & 0.13 & 0.83 \\
\hline Forage $(\mathrm{kg} / \mathrm{d})$ & $14.4^{\mathrm{ab}}$ & $14.0^{\mathrm{ab}}$ & $14.9^{\mathrm{a}}$ & $12.8^{\mathrm{b}}$ & 0.4 & 14.2 & 13.8 & 0.3 & $<0.01$ & 0.29 & $<0.01$ & 0.32 & 0.06 & 0.17 \\
\hline $\mathrm{EI}^{7}(\mathrm{~kJ} / \mathrm{kg} .75$ per day $)$ & $1,031^{\mathrm{ab}}$ & $1,037^{\mathrm{a}}$ & $1.092^{\mathrm{a}}$ & $948^{\mathrm{b}}$ & 19 & 1,035 & 1.021 & 14 & $<0.01$ & 0.17 & $<0.01$ & 0.13 & 0.04 & 0.19 \\
\hline $\mathrm{EB}^{8}\left(\mathrm{~kJ} / \mathrm{kg}^{0.75}\right.$ per dav $)$ & $-206^{\mathrm{a}}$ & $-234^{\mathrm{a}}$ & $-270^{\mathrm{ab}}$ & $-338^{\mathrm{b}}$ & 24 & $\begin{array}{l}-262 \\
-260\end{array}$ & $\begin{array}{l}-263 \\
-263\end{array}$ & 16 & $<0.01$ & 0.98 & $<0.01$ & 0.53 & 0.71 & 0.06 \\
\hline $\mathrm{BW}(\mathrm{kg})$ & $727.4^{\mathrm{ab}}$ & $699.6^{\mathrm{ab}}$ & $692.2^{\mathrm{b}}$ & $737.7^{\mathrm{a}}$ & 11.1 & 712.6 & 715.9 & 7.7 & 0.01 & 0.75 & $<0.01$ & 0.48 & $<0.01$ & 0.02 \\
\hline $\mathrm{BCS}^{9}$ & $3.0^{\mathrm{ab}}$ & $2.7^{\mathrm{b}}$ & $2.3^{\mathrm{c}}$ & $3.4^{\mathrm{a}}$ & 0.1 & 2.8 & 2.8 & 0.1 & $<0.01$ & 0.82 & $<0.01$ & 0.06 & 0.34 & 0.93 \\
\hline
\end{tabular}

${ }^{\mathrm{a}-\mathrm{c}}$ Values within the same row with different superscripts differ $(P<0.05)$.

${ }^{1}$ The study began with 130 cows (39 cows with a 0-d dry period, 41 cows with a 30-d dry period, and 50 cows with a 60-d dry period). However, 19 cows in the 0-d dry period group were attributed to a new group $(0 \rightarrow 67 \mathrm{~d}$ dry period) because these cows had a milk yield of $<4 \mathrm{~kg} / \mathrm{d}$ at least $30 \mathrm{~d}$ before expected calving date and were dried off without use of intramammary antibiotics.

${ }^{2} \mathrm{SEM}=$ pooled standard error of the least squares means.

${ }^{3} \mathrm{DPL}=$ dry period length; $\mathrm{D}=$ diet; $\mathrm{T}=$ time

${ }^{4} \mathrm{Wk} 1,2,3,4,5,6,7,8$, and 9 postcalving for all variables except BCS (mo 1 and 2 ).

${ }^{5}$ Fat- and protein-corrected milk.

${ }^{6} \mathrm{LnSCC}=$ natural logarithm of SCC.

${ }^{7}$ Energy intake; calculated with the VEM system (Van Es, 1975).

${ }^{8}$ Energy balance; calculated with the VEM system (Van Es, 1975)

${ }^{9}$ On a scale of 1 to 5 . 


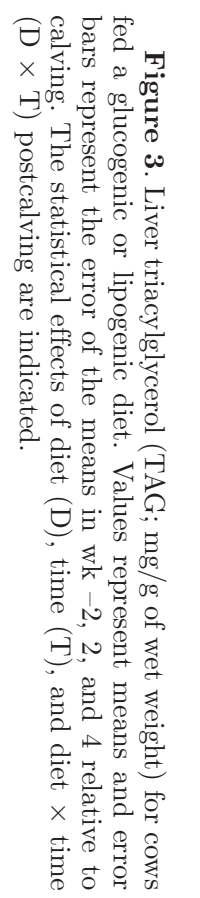

Liver TAG ( $\mathrm{mg} / \mathrm{g}$ of wet weight)

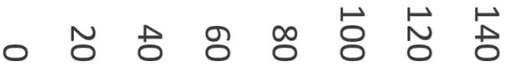

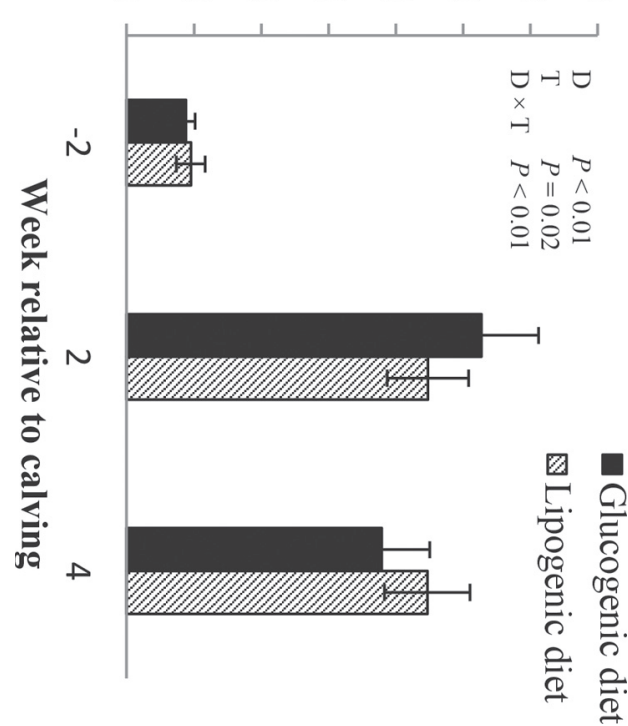

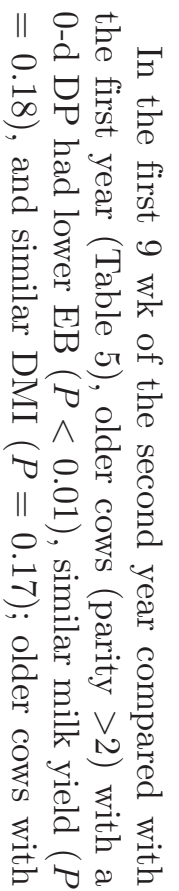
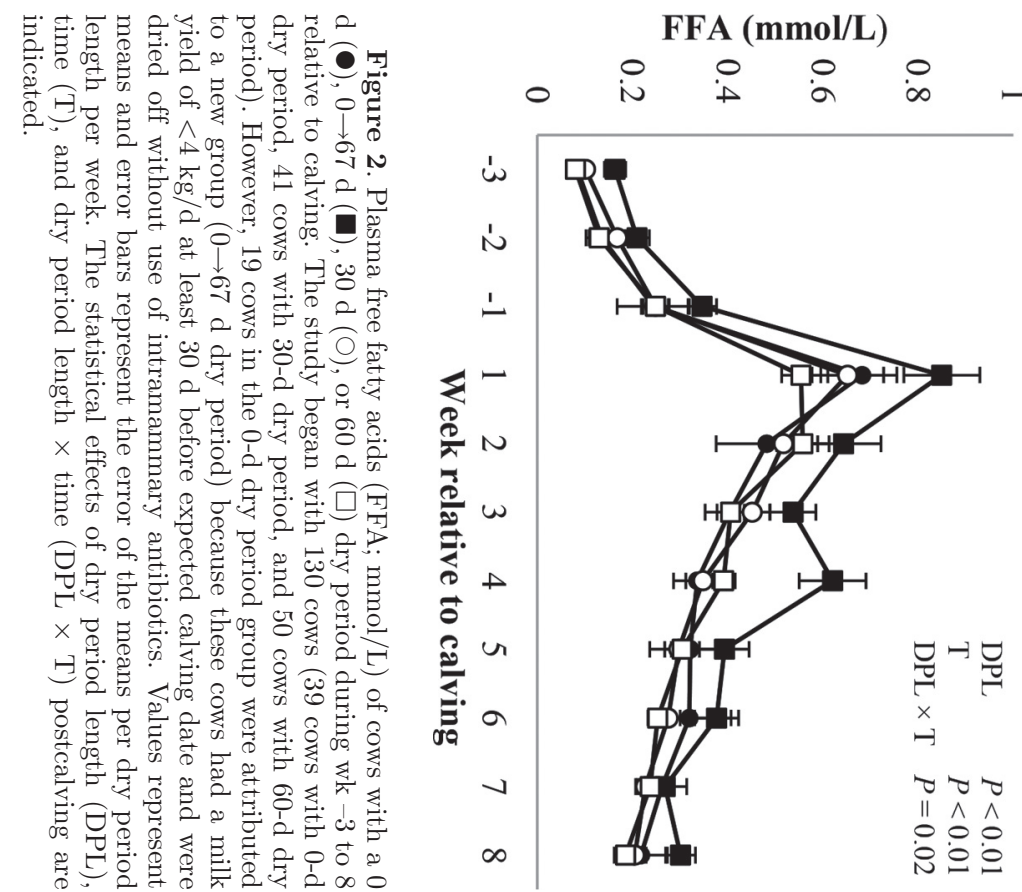

FFA (mmol/L)

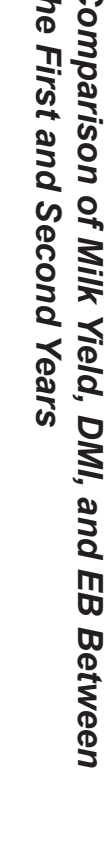

Table 3. Least squares means for plasma metabolites, hormones, and liver triacylglycerol of dairy cows in early lactation after a dry period of $0,30,60$, or $0 \rightarrow 67 \mathrm{~d}^{1}$ and fed either a glucogenic $(\mathrm{G})$ or a lipogenic $(\mathrm{L})$ diet

\begin{tabular}{|c|c|c|c|c|c|c|c|c|c|c|c|c|c|c|}
\hline \multirow[b]{2}{*}{ Item } & \multicolumn{4}{|c|}{ Dry period length (d) } & \multirow[b]{2}{*}{$\mathrm{SEM}^{2}$} & \multicolumn{2}{|c|}{ Diet } & \multirow[b]{2}{*}{ SEM } & \multicolumn{6}{|c|}{$P$-value ${ }^{3}$} \\
\hline & 0 & 30 & 60 & $0 \rightarrow 67$ & & G & $\mathrm{L}$ & & DPL & Diet & Time $^{4}$ & Parity & $\mathrm{DPL} \times \mathrm{T}$ & $\mathrm{D} \times \mathrm{T}$ \\
\hline Cows (no.) & 15 & 35 & 44 & 19 & & 58 & 55 & & & & & & & \\
\hline Free fatty acids $(\mathrm{mmol} / \mathrm{L})$ & $0.37^{\mathrm{b}}$ & $0.36^{\mathrm{b}}$ & $0.37^{\mathrm{b}}$ & $0.49^{\mathrm{a}}$ & 0.03 & 0.36 & 0.43 & 0.02 & $<0.01$ & $<0.01$ & $<0.01$ & $<0.01$ & 0.02 & 0.20 \\
\hline $\mathrm{BHB}^{5}(\mathrm{mmol} / \mathrm{L})$ & $0.82^{\mathrm{ab}}$ & $0.80^{\mathrm{b}}$ & $0.73^{\mathrm{b}}$ & $1.08^{\mathrm{a}}$ & 0.07 & 0.73 & 0.98 & 0.05 & $<0.01$ & $<0.01$ & $<0.01$ & 0.44 & 0.71 & 0.14 \\
\hline Glucose $(\mathrm{mmol} / \mathrm{L})$ & 3.33 & 3.27 & 3.27 & 3.19 & 0.06 & 3.36 & 3.17 & 0.04 & 0.54 & $<0.01$ & $<0.01$ & 0.24 & 0.71 & 0.53 \\
\hline Urea $(\mathrm{mmol} / \mathrm{L})$ & $2.87^{\mathrm{a}}$ & $2.84^{\mathrm{a}}$ & $2.74^{\mathrm{ab}}$ & $2.39^{\mathrm{b}}$ & 0.09 & 2.61 & 2.81 & 0.06 & 0.01 & 0.02 & $<0.01$ & 0.38 & 0.20 & $<0.01$ \\
\hline IGF-I (ng/mL) & $81.58^{\mathrm{a}}$ & $62.36^{\mathrm{b}}$ & $62.15^{\mathrm{b}}$ & $62.65^{\mathrm{b}}$ & 3.39 & 71.79 & 62.60 & 2.34 & $<0.01$ & $<0.01$ & $<0.01$ & $<0.01$ & 0.31 & 0.21 \\
\hline Insulin $(\mu \mathrm{IU} / \mathrm{mL})$ & $14.91^{\mathrm{a}}$ & $11.90^{\mathrm{b}}$ & $10.24^{\mathrm{b}}$ & $9.83^{\mathrm{b}}$ & 0.69 & 12.67 & 10.78 & 0.47 & $<0.01$ & $<0.01$ & $<0.01$ & 0.68 & 0.26 & 0.55 \\
\hline Cows (no.) & 10 & & 24 & 12 & & 36 & 35 & & & & & & & \\
\hline $\begin{array}{l}\text { Liver triacylglycerol } \\
\text { (mg/g of wet weight) }\end{array}$ & $44.1^{\mathrm{b}}$ & $90.7^{\mathrm{ab}}$ & $96.7^{\mathrm{a}}$ & $117.2^{\mathrm{a}}$ & 11.9 & 88.9 & 85.5 & 8.3 & $<0.01$ & $<0.01$ & 0.02 & 0.01 & 0.39 & $<0.01$ \\
\hline
\end{tabular}

${ }^{1}$ The study began with 130 cows (39 cows with a 0-d dry period, 41 cows with a 30-d dry period, and 50 cows with a 60 -d dry period). However, 19 cows in the 0-d dry period group were attributed to a new group $(0 \rightarrow 67 \mathrm{~d}$ dry period) because these cows had a milk yield of $<4 \mathrm{~kg} / \mathrm{d}$ at least $30 \mathrm{~d}$ before expected calving date and were dried off without use of intramammary antibiotics.

$8{ }^{2} \mathrm{SEM}=$ pooled standard error of the least squares means.

Z ${ }^{3} \mathrm{DPL}=$ dry period length; $\mathrm{D}=$ diet; $\mathrm{T}=$ time.

of Week 1, 2, 3, 4, 5, 6, 7, and 8 postcalving for plasma concentrations of free fatty acids, BHB, glucose, urea, IGF-I, and insulin; wk 2 and 4 postcalving for liver triacylglycerol concentration.

$\vec{\sigma}{ }^{5}$ Analyses were based on natural log-transformed data; back-transformed data are presented. 
Table 4. Least squares means for milk yield, DMI, energy balance, metabolites and hormones in early lactation for dairy cows categorized according to BCS before calving ${ }^{1}$

\begin{tabular}{|c|c|c|c|c|c|c|c|c|c|c|c|c|c|c|c|c|}
\hline \multirow[b]{2}{*}{ Item } & \multicolumn{2}{|c|}{$\mathrm{BCS}$} & \multirow[b]{2}{*}{$\mathrm{SEM}^{2}$} & \multicolumn{4}{|c|}{ Dry period length ${ }^{3}$ (d) } & \multirow[b]{2}{*}{ SEM } & \multicolumn{8}{|c|}{$P$-value ${ }^{4}$} \\
\hline & $<3.75$ & $\geq 3.75$ & & 0 & 30 & 60 & $0 \rightarrow 67$ & & BCS & DPL & Diet & Parity & Time $^{5}$ & $\mathrm{~B} \times \mathrm{DPL}$ & $\mathrm{B} \times \mathrm{T}$ & $\mathrm{B} \times \mathrm{P}$ \\
\hline Cows (no.) & 80 & 50 & & 20 & 41 & 50 & 19 & & & & & & & & & \\
\hline Milk yield (kg/d) & 39.5 & 40.6 & 0.9 & $37.4^{\mathrm{b}}$ & $40.0^{\mathrm{b}}$ & $42.9^{\mathrm{a}}$ & $41.0^{\mathrm{ab}}$ & 1.1 & 0.41 & $<0.01$ & 0.15 & 0.25 & $<0.01$ & 0.72 & 0.02 & 0.09 \\
\hline $\mathrm{FPCM}^{6}(\mathrm{~kg} / \mathrm{d})$ & 41.6 & 44.1 & 0.9 & $41.1^{\mathrm{b}}$ & $41.5^{\mathrm{b}}$ & $45.3^{\mathrm{a}}$ & $43.5^{\mathrm{ab}}$ & 1.1 & 0.04 & $<0.01$ & 0.37 & 0.47 & $<0.01$ & 0.99 & 0.93 & 0.08 \\
\hline Lactose $(\%)$ & 4.49 & 4.52 & 0.02 & 4.50 & 4.51 & 4.51 & 4.49 & 0.02 & 0.29 & 0.96 & 0.14 & $<0.01$ & $<0.01$ & 0.51 & 0.67 & 0.08 \\
\hline Fat $(\%)$ & 4.44 & 4.81 & 0.07 & 4.60 & 4.64 & 4.58 & 4.70 & 0.09 & $<0.01$ & 0.78 & 0.01 & 0.06 & $<0.01$ & 0.33 & 0.13 & 0.85 \\
\hline Protein (\%) & 3.45 & 3.43 & 0.05 & $3.62^{\mathrm{a}}$ & $3.49^{\mathrm{ab}}$ & $3.41^{\mathrm{ab}}$ & $3.24^{\mathrm{b}}$ & 0.07 & 0.83 & $<0.01$ & 0.37 & 0.43 & $<0.01$ & 0.09 & 0.92 & 0.44 \\
\hline $\operatorname{LnSCC}^{7}\left(\times 10^{3}\right.$ cells $\left./ \mathrm{mL}\right)$ & 4.8 & 4.8 & 0.1 & $5.0^{\mathrm{ab}}$ & $4.9^{\mathrm{a}}$ & $4.5^{\mathrm{b}}$ & $4.9^{\mathrm{ab}}$ & 0.2 & 0.69 & 0.02 & 0.86 & 0.06 & $<0.01$ & 0.07 & 0.60 & $<0.01$ \\
\hline DMI (kg/d) & 21.3 & 20.4 & 0.3 & $21.5^{\mathrm{ab}}$ & $20.4^{\mathrm{ab}}$ & $21.6^{\mathrm{a}}$ & $19.7^{\mathrm{b}}$ & 0.4 & 0.07 & $<0.01$ & 0.53 & 0.24 & $<0.01$ & 0.09 & 0.70 & 0.02 \\
\hline Concentrate $(\mathrm{kg} / \mathrm{d})$ & 6.9 & 6.9 & 0.0 & $6.9^{\mathrm{ab}}$ & $6.8^{\mathrm{b}}$ & $7.0^{\mathrm{a}}$ & $6.9^{\mathrm{ab}}$ & 0.1 & 0.92 & 0.04 & 0.13 & 0.23 & $<0.01$ & 0.21 & 0.53 & 0.53 \\
\hline Forage $(\mathrm{kg} / \mathrm{d})$ & 14.34 & 13.45 & 0.34 & $14.6^{\mathrm{ab}}$ & $13.6^{\mathrm{ab}}$ & $14.7^{\mathrm{a}}$ & $12.8^{\mathrm{b}}$ & 0.44 & 0.07 & $<0.01$ & 0.47 & 0.27 & $<0.01$ & 0.11 & 0.84 & 0.02 \\
\hline $\mathrm{EI}^{8}\left(\mathrm{~kJ} / \mathrm{kg}^{0.75}\right.$ per day $)$ & 1,064 & 979 & 14 & $1,039^{\mathrm{ab}}$ & $1,007^{\mathrm{b}}$ & $1,070^{\mathrm{a}}$ & $970^{\mathrm{b}}$ & 18 & $<0.01$ & $<0.01$ & 0.38 & 0.07 & $<0.01$ & 0.02 & 0.57 & 0.04 \\
\hline $\mathrm{EB}^{9}\left(\mathrm{~kJ} / \mathrm{kg}^{0.75}\right.$ per day $)$ & -231 & -327 & 19 & $-201^{\mathrm{a}}$ & $-271^{\mathrm{ab}}$ & $-302^{\mathrm{b}}$ & $-341^{\mathrm{b}}$ & 26 & $<0.01$ & $<0.01$ & 0.60 & 0.44 & $<0.01$ & 0.09 & 0.44 & 0.87 \\
\hline BW (kg) & 691.3 & 736.4 & 9.2 & 725.3 & 713.1 & 701.6 & 715.4 & 12.2 & $<0.01$ & 0.47 & 0.95 & 0.22 & $<0.01$ & 0.23 & $<0.01$ & 0.18 \\
\hline Cows (no.) & 68 & 45 & & 15 & 35 & 44 & 19 & & & & & & & & & \\
\hline Free fatty acids (mmol/L) & 0.36 & 0.45 & 0.02 & 0.37 & 0.40 & 0.38 & 0.48 & 0.02 & $<0.01$ & 0.08 & 0.04 & $<0.01$ & $<0.01$ & 0.33 & 0.13 & 0.24 \\
\hline $\mathrm{BHB}^{10}(\mathrm{mmol} / \mathrm{L})$ & 0.70 & 0.98 & 0.10 & 0.78 & 0.77 & 0.88 & 0.85 & 0.12 & $<0.01$ & 0.42 & $<0.01$ & 0.65 & $<0.01$ & 0.37 & 0.09 & 0.39 \\
\hline Glucose $(\mathrm{mmol} / \mathrm{L})$ & 3.25 & 3.22 & 0.05 & 3.31 & 3.23 & 3.21 & 3.18 & 0.07 & 0.68 & 0.63 & $<0.01$ & 0.29 & $<0.01$ & 0.03 & 0.02 & 0.43 \\
\hline Urea $(\mathrm{mmol} / \mathrm{L})^{\prime}$ & 2.80 & 2.65 & 0.08 & 2.89 & 2.80 & 2.74 & 2.46 & 0.10 & 0.19 & 0.11 & 0.03 & 0.46 & $<0.01$ & 0.45 & 0.60 & 0.88 \\
\hline IGF-I (ng/mL) & 62.49 & 67.40 & 2.80 & $79.56^{\mathrm{a}}$ & $60.85^{\mathrm{b}}$ & $63.62^{\mathrm{b}}$ & $55.74^{\mathrm{b}}$ & 3.86 & 0.24 & $<0.01$ & $<0.01$ & $<0.01$ & $<0.01$ & 0.06 & 0.71 & 0.68 \\
\hline Insulin $(\mu \mathrm{IU} / \mathrm{mL})$ & 11.40 & 11.81 & 0.61 & $14.87^{\mathrm{a}}$ & $12.04^{\mathrm{b}}$ & $10.26^{\mathrm{b}}$ & $9.24^{\mathrm{b}}$ & 0.83 & 0.64 & $<0.01$ & $<0.01$ & 0.79 & $<0.01$ & 0.91 & 0.61 & 0.75 \\
\hline Cows (no.) & 43 & 28 & & 10 & 25 & 24 & 12 & & & & & & & & & \\
\hline $\begin{array}{l}\text { Liver triacylglycerol } \\
\text { (mg/g of wet weight) }\end{array}$ & 80.2 & 105.4 & 9.3 & $42.7^{\mathrm{b}}$ & $95.4^{\mathrm{a}}$ & $110.4^{\mathrm{a}}$ & $124.6^{\mathrm{a}}$ & 12.3 & 0.19 & $<0.01$ & 0.82 & 0.04 & 0.02 & 0.09 & 0.28 & 0.26 \\
\hline
\end{tabular}

${ }^{\mathrm{a}, \mathrm{b}}$ Values within the same row with different superscripts differ $(P<0.05)$

${ }^{1}$ Month -1 and -2 relative to calving.

${ }^{2} \mathrm{SEM}=$ pooled standard error of the least squares means.

${ }^{3}$ The study began with 130 cows (39 cows with a 0-d dry period, 41 cows with a 30-d dry period, and 50 cows with a 60 -d dry period). However, 19 cows in the 0-d dry period group were attributed to a new group $(0 \rightarrow 67 \mathrm{~d}$ dry period) because these cows had a milk yield of $<4 \mathrm{~kg} / \mathrm{d}$ at least $30 \mathrm{~d}$ before expected calving date and were dried off without use of intramammary antibiotics.

${ }^{4} \mathrm{DPL}=$ dry period length; $\mathrm{B}=$ body condition score category; $\mathrm{T}=$ time; $\mathrm{P}=$ parity.

${ }^{5} \mathrm{Wk} 1,2,3,4,5,6,7,8$, and 9 postcalving for DMI, EB, and BW; mo 1 and 2 postcalving for BCS; wk 1, 2, 3, 4, 5, 6, 7, and 8 postcalving for concentrations of plasma free fatty acids, BHB, glucose, urea, IGF-I, and insulin; wk 2 and 4 postcalving for liver triacylglycerol concentration.

${ }^{6}$ Fat- and protein-corrected milk.

${ }^{7} \mathrm{LnSCC}=$ natural logarithm of SCC.

${ }^{8}$ Energy intake; calculated with the VEM system (Van Es, 1975).

${ }^{9}$ Energy balance; calculated with the VEM system (Van Es, 1975).

${ }^{10}$ Analyses were based on natural log-transformed data; back-transformed data are presented. 
a 30-d DP had lower EB $(P<0.01)$, similar milk yield $(P=0.61)$, and lower DMI $(P<0.01)$; older cows with a 60-d DP had similar negative EB $(P=0.52)$, similar milk yield $(P=0.14)$, and similar DMI $(P=0.24)$.

In the first 9 wk of the first year, milk yield losses were 14.2 and $4.1 \mathrm{~kg} / \mathrm{d}$ for young cows (parity = 2) with a 0 - or $30-\mathrm{d}$ DP, and were 9.9 or $5.4 \mathrm{~kg} / \mathrm{d}$ for older cows with a 0 - or 30-d DP, respectively, compared with cows with a $60-\mathrm{d}$ DP. In the first 9 wk of the first year, the difference of EB between cows with a 0- and 60-d DP was $311 \mathrm{~kJ} / \mathrm{kg}^{0.75}$ per day for young cows, and was $195 \mathrm{~kJ} / \mathrm{kg}^{0.75}$ per day for older cows. In the first $9 \mathrm{wk}$ of the second year, milk yield losses were 5.0 or 4.3 $\mathrm{kg} / \mathrm{d}$ for older cows with a 0 - or 30-d DP, respectively, compared with cows with a $60-\mathrm{d}$ DP. In the first $9 \mathrm{wk}$ of the second year, difference of EB between cows with a 0- and 60-d DP was $64 \mathrm{~kJ} / \mathrm{kg}^{0.75}$ per day. After correction for precalving BCS in the second year, milk yield losses of older cows with a 0- or 30-d DP were changed to 5.5 or $2.9 \mathrm{~kg} / \mathrm{d}$, respectively. In the second year after correction by precalving BCS, difference of EB between cows with a 0 - and 60-d DP was $101 \mathrm{~kJ} / \mathrm{kg}^{0.75}$ per day.

\section{DISCUSSION}

At the onset of lactation of the second year, cows with a 0-d DP had greater BCS compared with cows with a $60-d$ DP. This is because cows with a $0-d$ DP produced less milk in the first year but had similar energy intake compared with cows with a 60-d DP. This excess energy intake in the first year led to excessive weight gain in cows with a 0 -d DP $(\mathrm{BCS}=3.8)$ during the last 2 mo before the second calving. The high peripartal BCS could be related to the less-pronounced improvement of EB in cows with a 0-d DP in the second year compared with the first year. Roche et al. (2013) found that the extent of negative EB in early lactation increased with calving BCS. Indeed, after correction for precalving BCS in the current study, the EB contrast between cows with a 0-d DP (greater EB) and 60-d DP (lower EB) increased. Thus, a reduction in energy intake in the mid- and late-lactation periods may be necessary to prevent excessive weight gain in dairy cows when the DP is omitted. To our knowledge, the effects of a reduced energy intake (e.g., a reduced dietary energy content) on milk yield and EB after a 0-d DP are unknown. We can hypothesize that reduced dietary energy density in cows with a 0-d DP during mid and late lactation may improve EB, cow health, and welfare due to the 0-d DP and increases economic net herd returns by reducing feed costs.

The less-pronounced improvement of EB in the second year could also be related to smaller milk yield losses after 0-d DP compared with the first year. Dur-

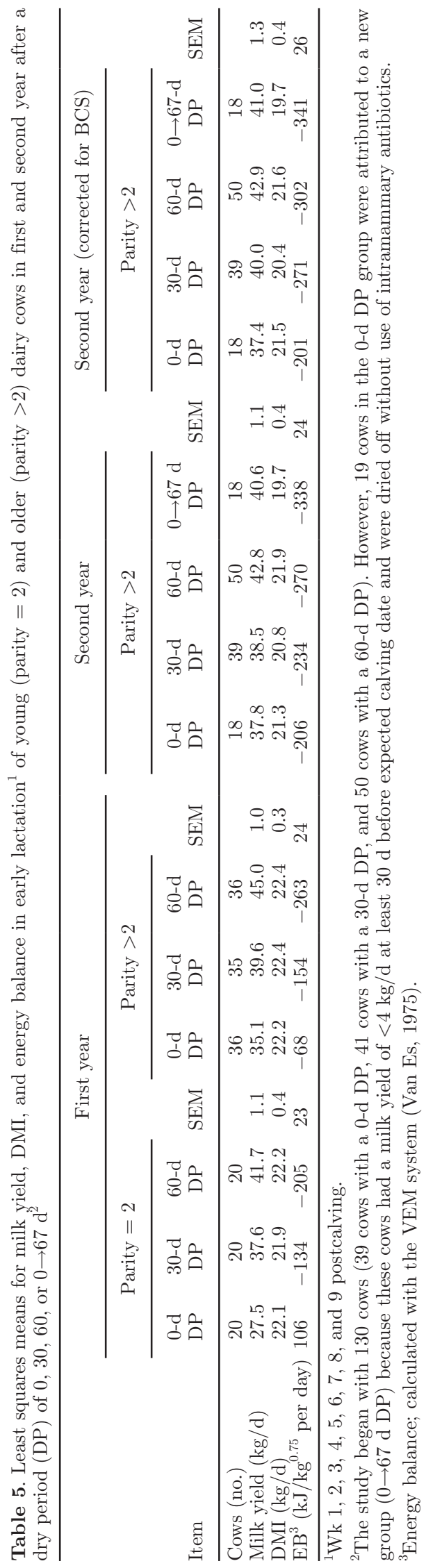

Journal of Dairy Science Vol. 99 No. 6, 2016 
ing the first $9 \mathrm{wk}$, cows with a 0 -d DP had a $25 \%$ lower milk yield in the first year and only a $12 \%$ lower milk yield in the second year compared with cows with a 60-d DP. This discrepancy could be related to the different distribution of parities in dairy cows between the first and second year. In the second year of the current study, all cows were older cows (parity >2). Annen et al. (2004) found that omitting the DP reduced milk yield in the subsequent lactation in young cows (parity $=2$ ), but not in older cows. Watters et al. (2008) suggested that fewer days dry are required to maximize milk yield in the subsequent lactation when cows increase in parity number. Moreover, in the first year of the current study, milk yield losses for cows with a $0-d$ DP were less in older cows compared with young cows (22 vs. $34 \%$ ). This parity sensitivity to omission of the DP could be due to continued mammary development in young cows during lactation (Collier et al., 2012). In addition, in the current study, cows with a 0-d DP had greater FPCM yield from wk -8 to 9 relative to calving compared with cows with a $60-\mathrm{d}$ DP. This result is in line with the finding in the first year of the current study, indicating that omitting the DP shifts milk yield from the postcalving to the precalving period (van Knegsel et al., 2014).

Although the improvement of EB was less pronounced, omitting the DP decreased liver TAG concentration in early lactation of the second year compared with 60-d DP. Together with our previous study (Chen et al., 2015a), this result suggests that omitting the DP could reduce the risk of fatty liver in early lactation over 2 consecutive years. Additionally, cows with a $0-d$ DP had greater plasma IGF-I and insulin concentrations compared with cows with other DP lengths in the second year, which is in accordance with previous studies in the first year after implementation of DP length treatment (Andersen et al., 2005; de Feu et al., 2009; Chen et al., 2015a). Greater plasma IGF-I and insulin concentrations could be caused by (1) lower milk yield and improved EB in cows with a 0-d DP in early lactation, or (2) carry-over effects of lactation diet-induced increase in plasma IGF-I and insulin concentrations before the second calving in cows with a 0 -d DP.

In the current study, omitting the DP increased LnSCC in early lactation of the second year compared with a 60-d DP. This finding is in agreement with the results of the first year of the current study (van Knegsel et al., 2014). The rise in LnSCC in cows with a 0-d DP can be explained partly by a decreased milk yield and, thus, a reduced diluting effect (Steeneveld et al., 2013). In the current study, when milk yield was included as a covariate in the model to analyze SCC, the effect of DP length on LnSCC was no longer present. Also, omission of preventive use of antibiotics in the weeks precalving in cows with a 0-d DP could contribute to the increased LnSCC.

Before the second calving, DP omission was achieved in 20 out of 39 cows assigned to the 0-d DP group in the current study, whereas DP omission was achieved in 2 out of 21 cows assigned to the $0-d$ DP group in the study of Rémond et al. (1997). The greater success in achieving DP omission over $2 \mathrm{yr}$ in the current study could be related to high genetic potential for milk yield and high feeding level in the cows (Rémond et al., 1997). In addition, these results indicate that not all cows could be milked continuously over 2 consecutive years because of low milk yield in late pregnancy. A short calving interval, which is related to greater milk yield in late pregnancy, could be a feasible approach to improve the achievement of DP omission. Earlier, several studies reported that omitting the DP reduced the interval from calving to resumption of ovarian cyclicity (Gümen et al., 2005; de Feu et al., 2009; Chen et al., 2015b). It can be hypothesized that when an earlier resumption of ovarian cyclicity is matched with an adjusted reproductive management (e.g., shorter voluntary waiting period or earlier insemination), it results in a shorter calving interval, which could lead to more cows achieving a 0-d DP during several consecutive years.

The cows that did not achieve a 0 -d DP $(0 \rightarrow 67 \mathrm{~d})$ had greater $\mathrm{BCS}(\mathrm{BCS}=4.2)$ during the last 2 mo before the second calving compared with cows with other DP lengths because of a lower milk yield and similar energy intake in the first year. Roche et al. (2009) suggested that an optimal BCS during calving should be between 3.0 and 3.25 , and that $\mathrm{BCS} \geq 3.5$ at calving is related to a decrease in DMI, more severe negative EB, and increased risk for metabolic disorders during the periparturient period. Indeed, cows with a $0 \rightarrow 67$-d DP had low energy intake and severe negative EB in the current study. A severe negative EB in cows with a $0 \rightarrow 67$-d DP in early lactation results in elevated body fat mobilization and an increase in plasma FFA concentration. Free fatty acids can enter the pathway of esterification and be stored as TAG or be incompletely oxidized to ketone bodies in liver (Drackley, 1999), which led to increased plasma BHB and liver TAG concentrations in cows with a $0 \rightarrow 67$-d DP in early lactation of the second year. However, after correction for precalving BCS, plasma concentrations of FFA and BHB in cows with a $0 \rightarrow 67$-d DP was no longer different from cows with other DP lengths. This result implies that poor metabolic status caused by negative EB in cows with a $0 \rightarrow 67$-d DP was mainly due to high BCS rather than DP length treatments.

In the first 9 wk of the second year, milk yield and FPCM did not differ between cows with a $0 \rightarrow 67$-d DP 
and cows with a 60-d DP in the current study. This high milk yield in cows with a $0 \rightarrow 67$-d DP could be due to a long DP in these cows, which allows replacement of damaged or senescent mammary epithelial cells before the subsequent lactation (Capuco et al., 1997). In agreement with our study, Rémond et al. (1997) reported that the cows that had an average 7 -d DP in the first year but an average 54-d DP in the second year had similar milk yield compared with cows with a conventional $60-d$ DP group. These results imply that milk yield level could be recovered in cows with a $0-d$ DP in previous lactation by drying off these cows again.

In early lactation of the second year, shortening the DP (30 d) resulted in less milk yield compared with a conventional DP, which is in line with results in the first year of the current study (van Knegsel et al., 2014) and in the study of Rastani et al. (2005). However, cows with a 30-d DP produced $297 \mathrm{~kg}$ of additional FPCM precalving because of an extended previous lactation. As a result, cows with a 30-d DP had a greater FPCM yield from wk -8 to 9 relative to calving compared with cows with a $60-\mathrm{d}$ DP.

Although shortening the DP reduced milk yield in early lactation, the improvement of EB in early lactation was less pronounced in the second year compared with the first year. The reduced improvement of $\mathrm{EB}$ was related to similar milk yield but lower DMI in cows with a 30-d DP in the second year compared with the first year. In addition, shortening the DP had no effects on LnSCC or metabolic status in the second year, which is in line with previous studies implementing a shortened DP for 1 yr (Rastani et al., 2005; Watters et al., 2008; van Knegsel et al., 2014). Furthermore, 31 of 41 cows assigned to $30-\mathrm{d}$ DP length treatment group had a DP length between 20 and $40 \mathrm{~d}$ before the second calving ( 3 cows had DP length $<20 \mathrm{~d}$ and 7 cows had DP length $>40 \mathrm{~d}$ ), indicating that implementing the strategy of shortening the DP is possible for 2 consecutive years in most dairy cows.

In the second year, feeding a glucogenic diet reduced milk fat percentage but tended to increase milk yield in early lactation compared with a lipogenic diet. Thus, the amount of energy partitioned to milk was similar, which led to similar EB in early lactation between cows fed a glucogenic diet and a lipogenic diets. Feeding a glucogenic diet compared with a lipogenic diet improved metabolic status independent of DP length, as indicated by decreased plasma FFA, BHB, and urea concentrations, and increased plasma IGF-I, insulin, and glucose concentrations. The high plasma glucose and insulin concentrations in cows fed the glucogenic diet could be related to its high starch content. Starch can be either fermented in the rumen to produce high amounts of propionate or digested in the small intestine and absorbed as glucose (van Knegsel et al., 2007b). Propionate is the major precursor for gluconeogenesis in dairy cows. In addition, a lipogenic diet is high in fiber and stimulates the ruminal production of lipogenic VFA (acetate and butyrate), which is related to increased plasma FFA and BHB concentrations (Moallem et al., 1997; Drackley et al., 1998, 2003).

Dietary effects on plasma metabolites were clearer in the second year compared with the first year after implementation of DP length treatments. There may be 2 explanations. First, feeding a glucogenic diet has more pronounced effects in older cows than in young cows in early lactation (van Knegsel et al., 2007a). Second, cows had a more severe negative EB in the second year compared with the first year. It can be hypothesized that a glucogenic diet could decrease fat mobilization and improve metabolic status in older cows and cows with severe negative EB.

Our results suggest that shortening the DP for 2 consecutive years is possible for most cows, with limited milk yield losses in the subsequent lactation. Omitting the DP is an option for cows with high persistency of lactation and high milk yield, but omitting the DP increases the risk of excessive weight gain in the subsequent lactation. In future studies, it will be necessary to test whether decreasing dietary energy density in mid and late lactation can prevent excessive weight gain and whether an earlier resumption of ovarian cyclicity and shorter calving interval can improve milk yield in late pregnancy and increase the proportion of cows that achieve a 0-d DP for several subsequent years.

\section{CONCLUSIONS}

Omitting the DP $(0 \mathrm{~d})$ in the second year did not result in improvement of $\mathrm{EB}$ as much as in the first year after implementation of DP length treatment, which was related to high BCS at the onset of lactation and smaller milk yield losses in cows with $0-d$ DP in the second year. In spite of the less pronounced improvement of EB, omitting the DP improved metabolic status in the early lactation of second year. Before the second calving, 19 of 39 cows in the 0-d DP group did not achieve a $0-d$ DP and were assigned to a new group $(0 \rightarrow 67 \mathrm{~d})$. Cows with a $0 \rightarrow 67$-d DP had more severe negative EB and poorer metabolic status compared with cows with a 0-, 30-, or 60-d DP. In the second year, omitting or shortening $(30 \mathrm{~d})$ the DP decreased milk yield compared with conventional DP (60 d), but additional milk produced precalving could compensate for milk yield losses in the first $9 \mathrm{wk}$ postcalving. Independent of DP length, a glucogenic diet, compared with a lipogenic diet, improved metabolic status without affecting EB in early lactation of the second year. 


\section{ACKNOWLEDGMENTS}

The authors thank the Dutch Dairy Board (PZ, the Netherlands), Product Board Animal Feed (PDV; the Netherlands), and CRV (the Netherlands) for financing the experiment. The first author thanks the Chinese Scholarship Council (CSC, China) for financial support. The authors thank the staff of the Dairy Campus (Lelystad, the Netherlands) and Veterinary Physiology Group of the University of Bern (Switzerland) for their technical support and laboratory analyses during the experiment. Additionally, the authors thank Danny de Koning (Wageningen University, Wageningen, the Netherlands) for editing this manuscript.

\section{REFERENCES}

Andersen, J. B., T. G. Madsen, T. Larsen, K. L. Ingvartsen, and M. O. Nielsen. 2005. The effects of dry period versus continuous lactation on metabolic status and performance in periparturient cows. J. Dairy Sci. 88:3530-3541.

Annen, E. L., R. J. Collier, M. A. McGuire, J. L. Vicini, J. M. Ballam, and M. J. Lormore. 2004. Effect of modified dry period lengths and bovine somatotropin on yield and composition of milk from dairy cows. J. Dairy Sci. 87:3746-3761.

Bachman, K. C., and M. L. Schairer. 2003. Invited review: Bovine studies on optimal lengths of dry periods. J. Dairy Sci. 86:30273037.

Capuco, A. V., R. M. Akers, and J. J. Smith. 1997. Mammary growth in Holstein cows during the dry period: Quantification of nucleic acids and histology. J. Dairy Sci. 80:477-487.

Chen, J., J. J. Gross, H. A. van Dorland, G. J. Remmelink, R. M. Bruckmaier, B. Kemp, and A. T. M. van Knegsel. 2015a. Effects of dry period length and dietary energy source on metabolic status and hepatic gene expression of dairy cows in early lactation. J. Dairy Sci. 98:1033-1045.

Chen, J., N. Soede, H. A. van Dorland, G. J. Remmelink, R. M. Bruckmaier, B. Kemp, and A. T. M. van Knegsel. 2015b. Relationship between metabolism and ovarian activity in dairy cows with different dry period lengths. Theriogenology 84:1387-1396.

Collier, R. J., E. L. Annen-Dawson, and A. Pezeshki. 2012. Effects of continuous lactation and short dry periods on mammary function and animal health. Animal 6:403-414.

CVB. 2005. Veevoedertabel. Gegevens over chemische samenstelling, verteerbaarheid en voederwaarde van voedermiddelen. CVB, Lelystad, the Netherlands.

de Feu, M. A., A. C. O. Evans, P. Lonergan, and S. T. Butler. 2009. The effect of dry period duration and dietary energy density on milk yield, bioenergetic status, and postpartum ovarian function in Holstein-Friesian dairy cows. J. Dairy Sci. 92:6011-6022.

Drackley, J. K. 1999. Biology of dairy cows during the transition period: The final frontier? J. Dairy Sci. 82:2259-2273.

Drackley, J. K., T. M. Cicela, and D. W. LaCount. 2003. Responses of primiparous and multiparous Holstein cows to additional energy from fat or concentrate during summer. J. Dairy Sci. 86:1306-1314.

Drackley, J. K., D. W. LaCount, J. P. Elliott, T. H. Klusmeyer, T. R. Overton, J. H. Clark, and S. A. Blum. 1998. Supplemental fat and nicotinic acid for Holstein cows during an entire lactation. J. Dairy Sci. 81:201-214.
Graber, M., S. Kohler, A. Muller, K. Burgermeister, T. Kaufmann, R. M. Bruckmaier, and H. A. van Dorland. 2012. Identification of plasma and hepatic parameters related to metabolic robustness in dairy cows. J. Anim. Physiol. Anim. Nutr. (Berl.) 96:75-84.

Gümen, A., R. R. Rastani, R. R. Grummer, and M. C. Wiltbank. 2005. Reduced dry periods and varying prepartum diets alter postpartum ovulation and reproductive measures. J. Dairy Sci. 88:2401-2411.

Moallem, U., M. Kaim, Y. Folman, and D. Sklan. 1997. Effect of calcium soaps of fatty acids and administration of somatotropin in early lactation on productive and reproductive performance of high producing dairy cows. J. Dairy Sci. 80:2127-2136.

Rastani, R. R., R. R. Grummer, S. J. Bertics, A. Gümen, M. C. Wiltbank, D. G. Mashek, and M. C. Schwab. 2005. Reducing dry period length to simplify feeding transition cows: milk yield, energy balance, and metabolic profiles. J. Dairy Sci. 88:1004-1014.

Rémond, B., J. Rouel, N. Pinson, and S. Jabet. 1997. An attempt to omit the dry period over three consecutive lactations in dairy cows. Ann. Zootech. 46:399-408.

Roche, J. R., N. C. Friggens, J. K. Kay, M. W. Fisher, K. J. Stafford, and D. P. Berry. 2009. Invited review: Body condition score and its association with dairy cow productivity, health, and welfare. J. Dairy Sci. 92:5769-5801.

Roche, J. R., K. A. Macdonald, K. E. Schutz, L. R. Matthews, G. A Verkerk, S. Meier, J. J. Loor, A. R. Rogers, J. McGowan, S. R. Morgan, S. Taukiri, and J. R. Webster. 2013. Calving body condition score affects indicators of health in grazing dairy cows. J. Dairy Sci. 96:5811-5825.

Steeneveld, W., Y. H. Schukken, A. T. M. Van Knegsel, and H. Hogeveen. 2013. Effect of different dry period lengths on milk yield and somatic cell count in subsequent lactations in commercial Dutch dairy herds. J. Dairy Sci. 96:2988-3001.

Tamminga, S., W. M. Van Straalen, A. P. J. Subnel, R. G. M. Meijer, A. Steg, C. J. G. Wever, and M. C. Blok. 1994. The Dutch protein evaluation system: The DVE/OEB-system. Livest. Prod. Sci. 40:139-155.

Van Es, A. J. 1975. Feed evaluation for dairy cows. Livest. Prod. Sci. 2:95-107.

van Knegsel, A. T. M., G. J. Remmelink, S. Jorjong, V. Fievez, and B. Kemp. 2014. Effect of dry period length and dietary energy source on energy balance, milk yield, and milk composition of dairy cows. J. Dairy Sci. 97:1499-1512.

van Knegsel, A. T. M., H. Van den Brand, J. Dijkstra, W. M. Van Straalen, R. Jorritsma, S. Tamminga, and B. Kemp. 2007a. Effect of glucogenic vs. lipogenic diets on energy balance, blood metabolites, and reproduction in primiparous and multiparous dairy cows in early lactation. J. Dairy Sci. 90:3397-3409.

van Knegsel, A. T. M., H. Van den Brand, E. Graat, J. Dijkstra, R. Jorritsma, E. Decuypere, S. Tamminga, and B. Kemp. 2007b. Dietary energy source in dairy cows in early lactation: Metabolites and metabolic hormones. J. Dairy Sci. 90:1477-1485.

Vicari, T., J. J. Van den Borne, W. J. Gerrits, Y. Zbinden, and J. W. Blum. 2008. Postprandial blood hormone and metabolite concentration influenced by feeding frequency and feeding level in veal calves. Domest. Anim. Endocrinol. 34:74-88.

Watters, R. D., J. N. Guenther, A. E. Brickner, R. R. Rastani, P. M. Crump, P. W. Clark, and R. R. Grummer. 2008. Effects of dry period length on milk yield and health of dairy cattle. J. Dairy Sci. 91:2595-2603.

Watters, R. D., M. C. Wiltbank, J. N. Guenther, A. E. Brickner, R R. Rastani, P. M. Fricke, and R. R. Grummer. 2009. Effect of dry period length on reproduction during the subsequent lactation. J. Dairy Sci. 92:3081-3090. 